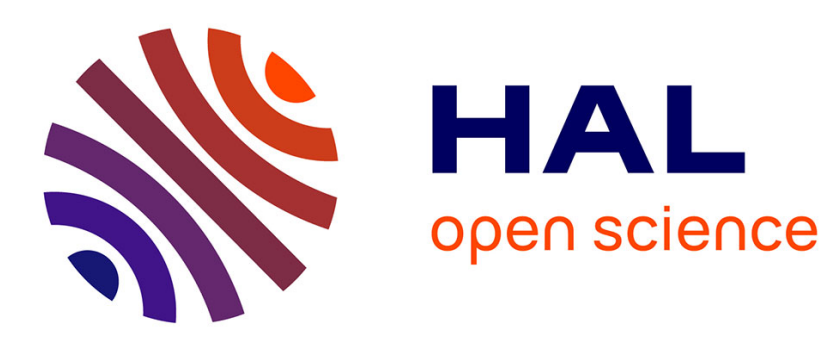

\title{
SUPPORTING LIFELONG LEARNING THROUGH DEVELOPMENT OF 21 ST CENTURY SKILLS
}

\author{
Nour El Mawas, Cristina Hava Muntean
}

\section{To cite this version:}

Nour El Mawas, Cristina Hava Muntean. SUPPORTING LIFELONG LEARNING THROUGH DEVELOPMENT OF 21 ST CENTURY SKILLS. 10th International Conference on Education and New Learning Technologies, Jul 2018, Palma de Mallorca, Spain. hal-02250150

\section{HAL Id: hal-02250150 https://hal.science/hal-02250150}

Submitted on 1 Aug 2019

HAL is a multi-disciplinary open access archive for the deposit and dissemination of scientific research documents, whether they are published or not. The documents may come from teaching and research institutions in France or abroad, or from public or private research centers.
L'archive ouverte pluridisciplinaire HAL, est destinée au dépôt et à la diffusion de documents scientifiques de niveau recherche, publiés ou non, émanant des établissements d'enseignement et de recherche français ou étrangers, des laboratoires publics ou privés. 


\title{
SUPPORTING LIFELONG LEARNING THROUGH DEVELOPMENT OF $21^{\text {ST }}$ CENTURY SKILLS
}

\author{
Nour El Mawas, and Cristina Hava Muntean \\ School of Computing, National College of Ireland, Dublin, Ireland \\ Nour.EIMawas@ncirl, ,Cristina.Muntean@ncirl.ie
}

\begin{abstract}
The new technology developments that are emerging on the market at a growing speed demand young people to quickly recognize the importance of lifelong learning. Re-skilling and updating competencies will be required in the near future, thus enabling learners of all ages to adapt to new expectations in the $21^{\text {st }}$ century workplace and life. Therefore, education should prepare learners for lifelong learning through development of $21^{\text {st }}$ century skills such as digital literacy, communication, collaboration, critical thinking, problem solving, decision making and creativity. This paper explores some $21^{\text {st }}$ century skills frameworks that have analysed and identified important skills that would support lifelong learning. Various pedagogies such as Problem-Based Learning, Flipped Classroom, Serious Games, Self-Directed Learning, Computer Supported Collaborative Learning and Personalised Learning that contribute to the development and mastery of $21^{\text {st }}$ century competencies and skills are discussed and compared.
\end{abstract}

Keywords: Lifelong learning, $21^{\text {st }}$ century skills frameworks, $21^{\text {st }}$ century pedagogies, Problem-Based Learning, Flipped Classroom, Serious Games, Self-Directed Learning, Computer Supported Collaborative Learning and Personalised Learning.

\section{INTRODUCTION}

Due to the new technologies that are coming on the market at a growing speed and of the fast technological changes of our world there is a need to continuously improve the population's skills, knowledge and competences. Therefore, we all have to be lifelong learners in order to be up to date, to develop ourselves and sharp our skills.

Lifelong learning is defined as "all learning activities undertaken by a person throughout life, with the aim of improving knowledge, skills and competences within a personal, civic, social and/or employmentrelated perspective" [1].

The learning activities may include formal, informal and non-formal learning. Formal learning consists of learning activities that take place within an organized context, for example in an educational institution or in-company training. A formal recognition (e.g. diploma) may be awarded at the end of the learning process. Non-formal learning represents that learning process that takes place within a set of activities that are not explicitly designated as learning but they do contain a learning element (e.g., practicing how to use an application/tool). Informal learning is that learning that occurs during daily life activities and it involves learning from own experience. Therefore, lifelong learning involves a continuous learning process, acquiring and expanding skills, behaviours and knowledge throughout the life of an individual.

The term lifelong learning has been used in the education or learning for more than 25 years but has become more important in the $21^{\text {st }}$ century due to increased life expectancy, and increased retirement age of workers. Due to the rapid change of technologies and global needs, companies have changed how they are organised, the way they do business as well as what they expect from their employees. 
Therefore, in order to succeed to secure a job, it is important to be a person open to learning new ideas, regardless of your age and realise that education should not stop when you graduate.

There are many benefits of lifelong learning in addition to increasing job prospects and supplementing professional competence such as it helps to keep the mind sharp and improve memory, enhances selfesteem, helps us to adapt to society's changes, helps us to make new friends as we are meeting new people during the learning activities.

In order to become a lifelong learner a person must have developed $21^{\text {st }}$ century skills such as digital literacy, communication, critical thinking, problem solving, collaboration, creativity and imagination, in order to be able to identify the learning activities he/she has to undertake in order to improve his/her knowledge and skills.

[2] argue that learners do not develop $21^{\text {st }}$ century competencies and skills unless they are explicitly taught. Therefore, there is a need for formal education to transform in order to enable new forms of learning and applicability of new pedagogy methods that support acquisition of competencies and skills.

Some pedagogy methods are more successful than others in helping students to develop $21^{\text {st }}$ century skills. For example, pedagogy methods that support personalised learning, collaborative learning, problem solving through negotiation and collaboration, applicability of newly acquired skills and knowledge support deeper learning and lifelong learning [3] [4]. $21^{\text {st }}$ century pedagogy must employ innovative and research supported teaching strategies, learning technologies and real world applications [2].

This paper explores $21^{\text {st }}$ century skills frameworks that identify various skills as been important for the $21^{\text {st }}$ century and support lifelong learning. Pedagogies that may contribute to the development and mastery of $21^{\text {st }}$ century competencies and skills are also discussed.

\section{$2 \quad 21^{\text {ST }}$ CENTURY SKILLS FRAMEWORKS}

Despite widespread agreement on their importance of the $21^{\text {st }}$ century skills, however, there still appears to be disagreement on what particular skills are important.

Numerous $21^{\text {st }}$ century skills frameworks exist that identify different skills as important and they are presented next.

The Assessment and Teaching of $21^{\text {st }}$ Century Skills (ATC21S) project [5] develops a framework consisting of a hierarchy of skills that play a pivotal role in collaborative problem solving. Due to the role of technology in the workplace and life styles, new skills were needed as well as new emphases on older skills.

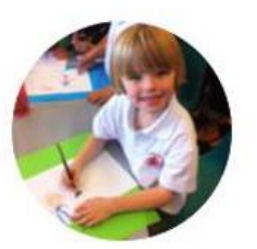

Ways of Thinking

- Creativity and innovation

- Critical thinking

problem solving

- Learning to learn

and meta cognition

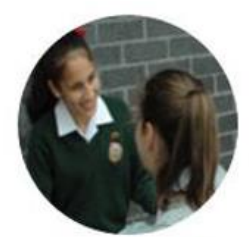

Ways of Working

- Communication

- Collaboration and teamwork

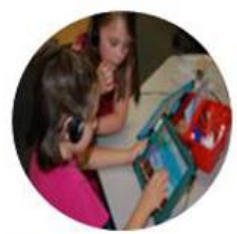

Tools for

Working

- Information literacy

- ICT literacy

Learning to learn

and meta cognition

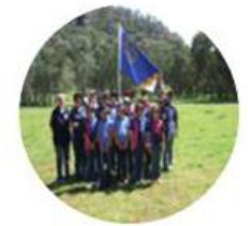

Living in the real world

- Citizenship, local and global

- Life and career

- Personal and social

responsibility

Knowledge Skills Attitudes Values Ethics

Figure 1. KSAVE Framework [5] 
Figure 1 illustrates the KSAVE (Knowledge, Skills, Attitudes, Values and Ethics.) framework proposed in ATC21S project. Four sets of skills were recognized as essential for adjustments to the effect of technology on life, learning and work. The skills were identified as those which would enable people to demonstrate new ways of thinking, ways of working, use tools for working and living in the world that had emerged as a result of technology. Ways of thinking includes creativity and innovation, critical thinking, problem-solving, and learning to learn and the development of metacognition. Ways of working involves communication, collaboration and teamwork. Tools for working involves information and ICT literacy. Living in the real world covers changing emphases on local and global citizenship, aspects of life and career development, and personal and social responsibility.
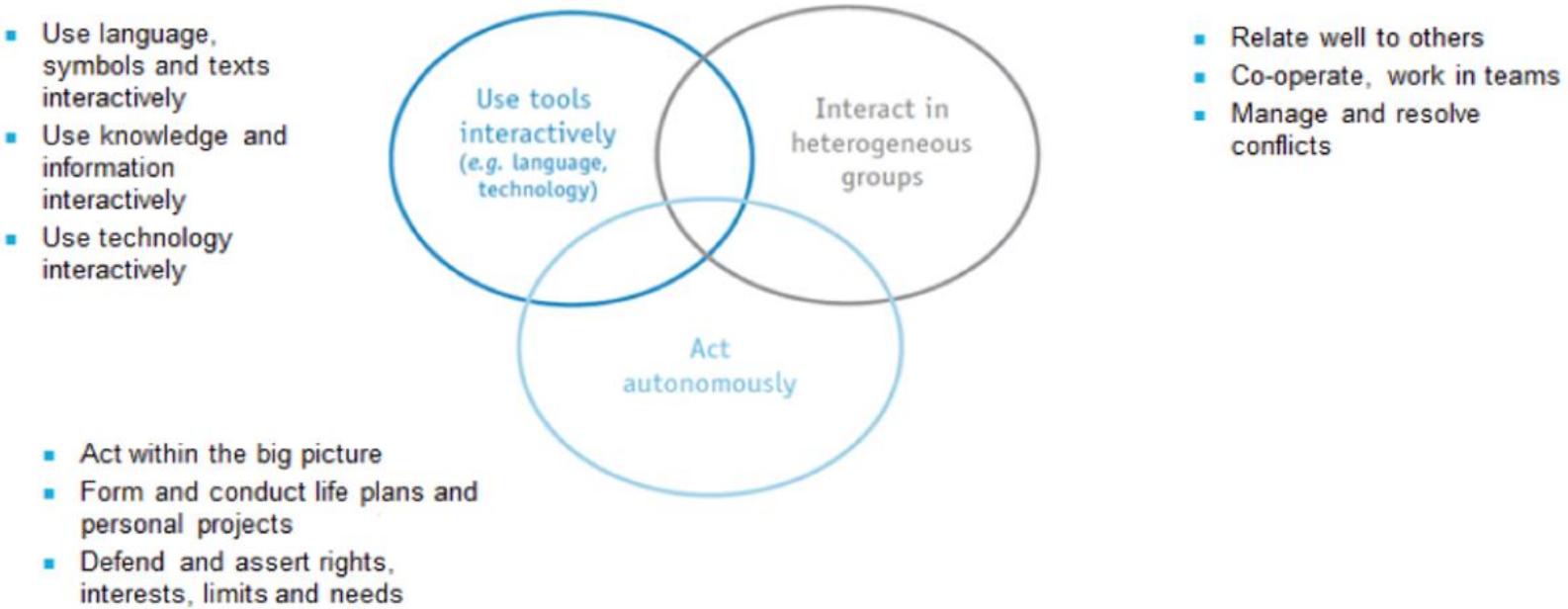

Figure 2. The OECD Framework.

The Organization for Economic Cooperation and Development (OECD) proposed key competencies that people must develop as part of $21^{\text {st }}$ century skills and support lifelong learning [6]. These key competencies were classified in three categories (see Figure 2): interacting in socially heterogeneous groups, acting autonomously, and using tools interactively. Interacting in socially heterogeneous groups, are particularly relevant in pluralistic, multicultural societies. Individuals need to learn how to join and function in groups and social orders whose members are from diverse backgrounds and how to deal with differences and contradictions. Acting autonomously includes key competencies that empower individuals to manage their lives in meaningful and responsible ways by exercising control over their living and working conditions like the ability to act within the larger context; to form and conduct life plans and personal projects; and the ability to defend and assert rights, interests, limits, and needs. Using tools interactively represents the social and professional demands of the global economy and modern society including the mastery of such socio-cultural tools as language, information, and knowledge, as well as such physical tools as computers. Using tools interactively does not simply mean having the technical skills to use a tool but assumes a familiarity with the tool itself and an understanding of how the tool changes the way one can interact with the world and how the tool is used to accomplish broader goals.

The United Nations Educational, Scientific and Cultural Organization (UNESCO) proposed a competence approach [5] [7] based on four pillars of learning that support development of $21^{\text {st }}$ century skills: learning to know, learning to do, learning to be, and learning to live together. "Learning to know" includes developing the faculties of memory, reasoning and problem solving; it pre-supposes learning to learn and could usefully be extended to the concept of knowledge building. "Learning to do" implies acquisition of complex skills, but also refers to developing an aptitude for teamwork and initiative, and a readiness to take risks. "Learning to be" is founded on the fundamental principle that education needs to contribute to the all-round development of each individual. This pillar deals with what it is to be human, comprehended by intellectual, moral, cultural and physical dimensions. "Learning to live" together refers to developing an understanding of others as well as highlighting the reality that if we are to understand others, we must first know ourselves. 
Another framework that seeks the development of $21^{\text {st }}$ century skills that support lifelong learning is Partnerships 21 (P21) Framework for 21st Century Learning [8]. The framework was developed with input from educators, education experts, and business leaders to define and illustrate the skills, knowledge, expertise, and support systems that students need to succeed in work, life, and citizenship. The Framework is composed of 4 elements (see Figure 3): (1) Life and Career Skills, (2) Learning and Innovation Skills, (3) Information, Media, and Technology Skills, and (4) Key Subjects and $21^{\text {st }}$ Century Themes.

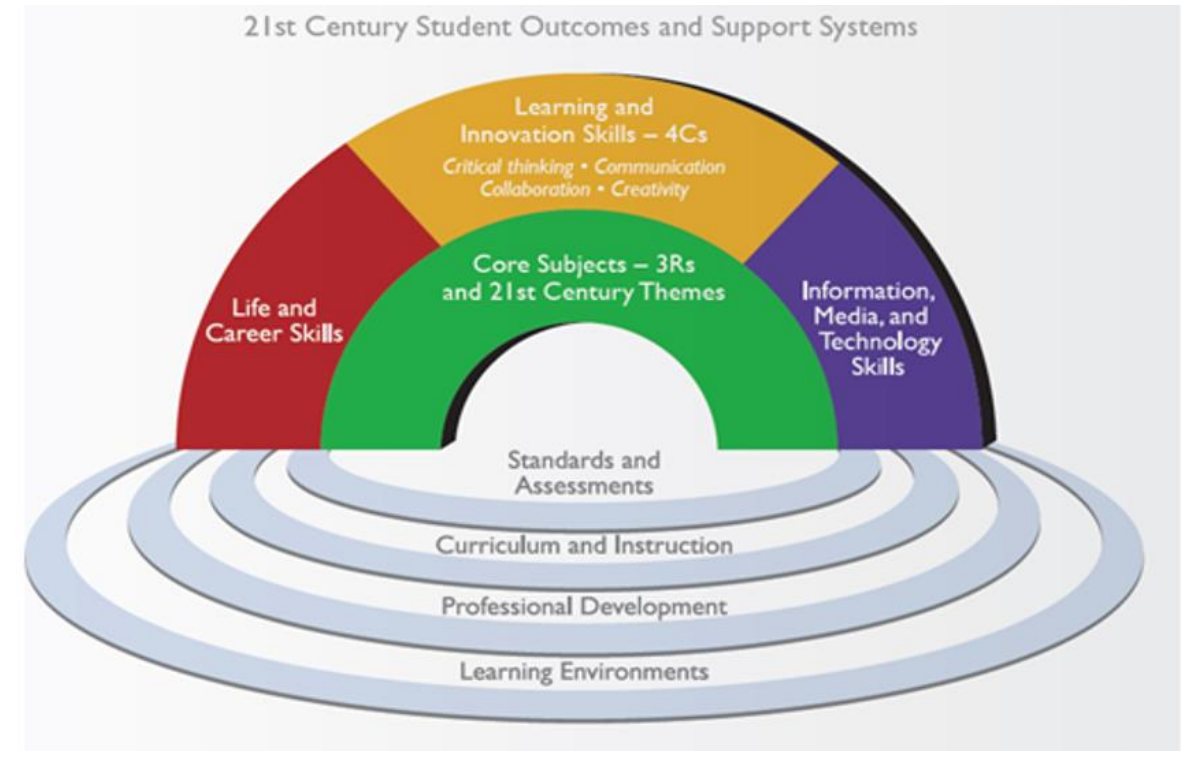

Figure 3. Partnerships 21 Framework.

All elements of the Framework are critical to ensure $21^{\text {st }}$ century readiness for every student. Students need Life and Career Skills to develop thinking skills, content knowledge, and social and emotional competencies in order to navigate complex life and work environments. They include flexibility and adaptability, initiative and self-direction, social and cross-cultural skills, productivity and accountability, and leadership and responsibility. Learning and innovation skills are what separate students who are prepared for increasingly complex life and work environments in today's world and those who are not. They include creativity and innovation, critical thinking and problem solving, communication, and collaboration. Information, Media and Technology Skills are important because we live in a technology and media-driven environment, marked by access to an abundance of information, rapid changes in technology tools and the ability to collaborate and make individual contributions on an unprecedented scale. Effective citizens and workers must be able to exhibit a range of functional and critical thinking skills, such as information literacy, media literacy, and ICT (Information, Communications and Technology) literacy. Key Subjects and 21st Century Themes include English, reading or language arts, world languages, arts, mathematics, economics, science, geography, history, government and civics. In addition, schools must promote an understanding of academic content at much higher levels by weaving $21^{\text {st }}$ century interdisciplinary themes into 5 key subjects: global Awareness, financial, economic, business and entrepreneurial Literacy, civic Literacy, health Literacy, and environmental Literacy.

An in-depth analysis of these frameworks shows that there are overlaps among these frameworks (see Table 1) in terms of proposed skills. For example, P21's "learning and innovation skills" matches to some ATC21S's "ways of thinking" and "ways of working" set of skills. P21's "Information, Media, and Technology Skills" is comparable to ATC21S 21's "Ways of thinking", "Tools for working", and "Living in the real world" sets of skills. 
Table 1. Similarities between different frameworks.

\begin{tabular}{|c|c|c|c|}
\hline ATC21S & OECD & UNESCO & P21 \\
\hline $\begin{array}{l}\text { Ways of thinking } \\
\text { (creativity and } \\
\text { innovation, critical } \\
\text { thinking, problem- } \\
\text { solving, and learning to } \\
\text { learn and the } \\
\text { development of } \\
\text { metacognition) }\end{array}$ & & $\begin{array}{l}\text { Learning to know } \\
\text { (developing the } \\
\text { faculties of } \\
\text { memory, reasoning } \\
\text { and problem } \\
\text { solving) }\end{array}$ & $\begin{array}{l}\text { - Learning and Innovation } \\
\text { Skills } \\
\text { (creativity and innovation, } \\
\text { critical thinking and problem } \\
\text { solving) } \\
\text { - Information, Media, and } \\
\text { Technology Skills } \\
\text { (critical thinking) } \\
\text { - Life and Career Skills } \\
\text { thinking skills (content } \\
\text { knowledge) }\end{array}$ \\
\hline $\begin{array}{l}\text { Ways of working } \\
\text { (communication, } \\
\text { collaboration and } \\
\text { teamwork) }\end{array}$ & $\begin{array}{l}\text { Interacting in } \\
\text { socially } \\
\text { heterogeneous } \\
\text { groups }\end{array}$ & $\begin{array}{c}\text { - Learning to do } \\
\text { (developing an } \\
\text { aptitude for } \\
\text { teamwork and } \\
\text { initiative, and a } \\
\text { readiness to take } \\
\text { risks) } \\
\text { - Learning to live } \\
\text { together } \\
\text { (understanding of } \\
\text { ourselves / others) }\end{array}$ & $\begin{array}{c}\text { - Learning and Innovation } \\
\text { Skills (communication, and } \\
\text { collaboration) } \\
\text { - Life and Career Skills } \\
\text { thinking skills (social and } \\
\text { emotional competencies / } \\
\text { social and cross-cultural skills) }\end{array}$ \\
\hline $\begin{array}{c}\text { Tools for working } \\
\text { (information and ICT } \\
\text { literacy) }\end{array}$ & $\begin{array}{l}\text { Using tools } \\
\text { interactively } \\
\text { (mastery of } \\
\text { language, } \\
\text { information, } \\
\text { knowledge, and } \\
\text { physical tools) }\end{array}$ & $\begin{array}{l}\text { Learning to do } \\
\text { (acquisition of } \\
\text { complex skills) }\end{array}$ & $\begin{array}{l}\text { Information, Media, and } \\
\text { Technology Skills ( } \\
\text { technology and media-driven } \\
\text { environment, information } \\
\text { literacy, media literacy, and } \\
\text { ICT literacy) }\end{array}$ \\
\hline $\begin{array}{l}\text { Living in the real world } \\
\text { (local and global } \\
\text { citizenship, aspects of } \\
\text { life and career } \\
\text { development, and } \\
\text { personal and social } \\
\text { responsibility) }\end{array}$ & $\begin{array}{c}\text { Acting } \\
\text { autonomously } \\
\text { (control living and } \\
\text { working conditions) }\end{array}$ & $\begin{array}{l}\text { Learning to be } \\
\text { (intellectual, moral, } \\
\text { cultural and } \\
\text { physical } \\
\text { dimensions) }\end{array}$ & $\begin{array}{c}\text { - Information, Media, and } \\
\text { Technology Skills } \\
\text { (Effective citizens) } \\
\text { - Life and Career Skills } \\
\text { (flexibility and adaptability, } \\
\text { initiative and self-direction, } \\
\text { productivity, accountability, } \\
\text { leadership and responsibility) }\end{array}$ \\
\hline
\end{tabular}




\section{TEACHING APPROACHES THAT SUPPORT LIFELONG LEARNING AND $21^{\text {ST }}$ CENTURY SKILLS}

Pedagogy methods that help students to develop $21^{\text {st }}$ century skills are presented next. In particular Problem-Based Learning (PBL), Flipped Classroom (FC), Serious Games (SGs), Self-Directed Learning (SDL), Computer Supported Collaborative Learning (CSCL) and Personalised Learning (PL) are discussed and their role in developing $21^{\text {st }}$ century skills is highlighted.

Problem-based Learning (PBL) is a pedagogy in which students learn by solving real-world or openended problems. [9] defines PBL as an instructional (and curricular) learner-centred approach that empowers learners to conduct research, integrate theory and practice, and apply knowledge and skills to develop a viable solution to a defined problem. PBL is ideal instructional models for meeting the objectives of twenty-first century education [10], because they employ the 4Cs Principle (critical thinking, communication, collaboration and creativity) alongside 'teaching for transfer' and learning structured in real world contexts. In addition, they motivate learners to manage their own time and efforts and publically present their work. These are valuable skills for the twenty-first century workplace [8]. The PBL help students to develop flexible knowledge, problem identification and problem-solving skills, self-directed learning, and effective collaboration skills [11], [12].

According to [13], Flipped Classroom (FC) represents a pedagogical model in which the typical lecture and homework elements of a course are reversed. Short video lectures are viewed by students at home before the class session, while in-class time is devoted to exercises, projects, or discussions [14]. The FC has an important role to develop $21^{\text {st }}$ century skills ${ }^{1}$. It promotes independent learning, critical thinking, collaboration, digital literacy, digital citizenship, creativity, and social skills. By moving direct instruction outside of the classroom, students are encouraged to engage in metacognitive learning and to learn independently. Through FC, students are encouraged to think critically, thus promoting their curiosity and broadening their knowledge. Through the FC approach, students collaborate effectively using social media outside the school, while the classroom itself becomes a hub for debate with peers, reflection, and guided writing. By using the technology to view lessons, interact and collaborate, students' digital literacy is fostered because learners use their devices as platforms for learning and development and not only as social accessories. FC encourages students to work side by side in a digital environment which teach them the basics of respect and cooperation in an online world. That is why their digital citizenship is enhanced. When students learn outside the classroom, their creativity and innovation are fostered. By converting the classroom into a more active, collaborative workspace students develop their social skills.

Serious Games (SGs) are games that do not have entertainment, enjoyment or fun as their primary purpose [15]. SGs have an explicit and carefully thought-out educational purpose and are not intended to be played primarily for amusement. This does not mean that serious games are not, or should not be, entertaining [16]. SGs have a key role to develop the skills needed in the $21^{\text {st }}$ century. According to [17], SGs enable an active learning approach that encourages critical thinking, group communication, debate and decision making. [18] highlight the contribution of $S G$ to developing self-regulation, information skills, networked co-operation, problem solving strategies and critical thinking.

Self-Directed Learning (SDL) [19] describes a process in which individuals take the initiative, with or without the help of others, in diagnosing their learning needs, formulating learning goals, identifying human and material resources for learning, choosing and implementing appropriate learning strategies, and evaluating learning outcomes. SDL promotes creativity and innovation which are $21^{\text {st }}$ century skills. It changes teaching and learning process in order to prepare our students to be successful in their future. [20] considers that risk-taking and commitment to continuous learning are specifications of self-directed learners, who succeed by differentiating their skills and exploiting informal learning technologies available to them.

Computer Supported Collaborative Learning (CSCL) [21] encourages students to see situations from different perspectives, creates an environment where they can practice social and leadership skills (social benefits), and provides a satisfactory learning experience that significantly reduces anxiety. CSCL examines how to use technology as a scaffolding tool to support collaboration and higher order thinking. Many studies are done on how CSCL fosters higher order thinking by focusing of argumentation, such as drawing reasons to support idea, finding evidence, and drawing a valid conclusion [22].

\footnotetext{
${ }^{1}$ http://fishtreeblog.tumblr.com/post/102878026250/the-21st-century-skills-of-the-flipped-classroom
} 
Personalised Learning (PL) shifts from the 'one-size-fits-all' approach, specific to traditional education, to a learning process specific to the individuals [23]. [3] stress that "personalization has implications for what, how and where we teach". Learners can approach problems in their own way and their own pace. This methodology develops learners' individual sense of wonder and inspires them to explore different applications for the knowledge and skills they have learned. Personalised Learning provides greater autonomy and inspires learner to take control of their learning [24]. Personalised Learning can be achieved by using online learning systems and tools that support a student-centred learning. These learning environments help students to acquire knowledge but also to develop and demonstrate $21^{\text {st }}$ century skills such as communication, collaboration, problem solving and creativity by using, creating and sharing digital content.

After presenting six teaching approaches (pedagogy methods) that develop $21^{\text {st }}$ centuries skills that further support the lifelong learning, Table 2 summarizes the skills that are developed by each pedagogy. For example, FC and CSCL support critical thinking, communication, collaboration, and digital literacy. In addition, CSCL develops the creativity skills. Digital literacy skill is developed by almost all pedagogies exempt PBL. Creativity a very important skills required in the $21^{\text {st }}$ century is enhanced through PBL. FC, SDL and PL.

Table 2. Teaching approaches vs $21^{\text {st }}$ century skills.

\begin{tabular}{c|c|c|c|c|c|c}
\hline & PBL & FC & SG & SDL & CSCL & PL \\
\hline Critical thinking & $\mathrm{x}$ & $\mathrm{x}$ & $\mathrm{x}$ & $\mathrm{x}$ & $\mathrm{x}$ & \\
\hline Decision making & & & $\mathrm{x}$ & & & $\mathrm{x}$ \\
\hline Problem solving & $\mathrm{x}$ & & $\mathrm{x}$ & & & $\mathrm{x}$ \\
\hline Risk taking & & & & $\mathrm{x}$ & & \\
\hline Creativity & $\mathrm{x}$ & $\mathrm{x}$ & & $\mathrm{x}$ & & $\mathrm{x}$ \\
\hline Communication & $\mathrm{x}$ & $\mathrm{x}$ & $\mathrm{x}$ & & $\mathrm{x}$ & $\mathrm{x}$ \\
\hline Collaboration & $\mathrm{x}$ & $\mathrm{x}$ & & & $\mathrm{x}$ & \\
\hline Digital literacy & & $\mathrm{x}$ & $\mathrm{x}$ & $\mathrm{x}$ & $\mathrm{x}$ & \\
\hline Digital citizenship & & $\mathrm{x}$ & & & $\mathrm{x}$ & \\
\hline
\end{tabular}

\section{CONCLUSIONS}

Re-skilling and updating competencies will be required in the near future, due to the rapid technology advancements that come in our workplace and day-to day life activities. In order to cope with these fast changes people will have to change into a lifelong learner and develop $21^{\text {st }}$ century skills.

Four $21^{\text {st }}$ century skills frameworks that have identified a set of required $21^{\text {st }}$ century skills are presented and compared. The paper also discussed and compared six pedagogies that the current education systems should apply in the learning and teaching process in order to ensure the development of the $21^{\text {st }}$ century skills such as digital literacy, communication, collaboration, critical thinking, problem solving, decision making and creativity, thus fostering long-life learning.

\section{ACKNOWLEDGEMENTS}

This research is supported by the NEWTON project (http://www.newtonproject.eu/) funded under the European Union's Horizon 2020 Research and Innovation programme, Grant Agreement no. 688503. 


\section{REFERENCES}

[1] E. Commission (EC), "Making a European area of lifelong learning a reality," 2001.

[2] A. R. Saavedra and V. D. Opfer, "Teaching and Learning 21st Century Skills," 2012.

[3] C. Redeker et al., "The future of learning: Preparing for change," 2012.

[4] N. El Mawas, M. Bradford, J. Andrews, P. Pathak and C. H. Muntean, "A Case study on 21st century skills development through a computer based maths game", AACE EDMEDIA Innovative Learning. Amsterdam, June

[5] P. Griffin and E. Care, "Developing learner's colllborative problem solving skills", European Schoolnet Academy, 2014.

[6] D. S. Rychen and L. H. Salganik, "Definition and selection of competencies: Theoretical and conceptual foundations (DeSeCo)," Summ. Final Rep. Key Competencies Success. Life WellFunct. Soc., 2003.

[7] J. Delors, "The treasure within: Learning to know, learning to do, learning to live together and learning to be. What is the value of that treasure 15 years after its publication?" Int. Rev. Educ., vol. 59, no. 3, pp. 319-330, 2013.

[8] "Partnership for $21^{\text {st }}$ Century Skills." The Partnership for $21^{\text {st }}$ Century Learning, 2015.

[9] J. R. Savery, "Overview of problem-based learning: Definitions and distinctions," Interdiscip. J. Probl.-Based Learn., vol. 1, no. 1, p. 3, 2006.

[10] C. Luna Scott, "The Futures of Learning 3: what kind of pedagogies for the $21^{\text {st }}$ Century?," 2015.

[11] E. T. Christiansen, L. Kuure, A. Mørch, and B. Lindström, Problem-based Learning for the $21^{\text {st }}$ Century: New Practices and Learning Environments. Aalborg Universitetsforlag, 2013.

[12] C. E. Hmelo-Silver, "Problem-based learning: What and how do students learn?" Educ. Psychol. Rev., vol. 16, no. 3, pp. 235-266, 2004.

[13] Educause Learning, "Things you should know about flipped classrooms," Educ. Creat. Commons, 2007.

[14] M. Bradford, C. H. Muntean, P. Pathak, "An Analysis of flip classroom pedagogy in first year undergraduate mathematics for computing", in IEEE Frontiers in Education Conference, Madrid, Spain, pp.1-5, 2014

[15] D. R. Michael and S. L. Chen, "Serious games: Games that educate, train, and inform", Muska \& Lipman/Premier-Trade, 2005.

[16] C. C. Abt,, "Serious games", University press of America, 1987.

[17] M. Pivec, "Play and learn: potentials of game-based learning," Br. J. Educ. Technol., vol. 38, no. 3, pp. 387-393, 2007.

[18] W. Westera, R. Nadolski, H. G. Hummel, and I. G. Wopereis, "Serious games for higher education: a framework for reducing design complexity," in Journal Computer. Assisted Learnning, vol. 24, no. 5, pp. 420-432, 2008.

[19] M. S. Knowles, "Self-directed learning," 1975.

[20] S. Herring, "Transforming the workplace: Critical skills and learning methods for the successful $21^{\text {st }}$ century worker," Big Think, 2012.

[21] A. García-Valcárcel, V. Basilotta, and C. López, "ICT in Collaborative Learning in the Classrooms of Primary and Secondary Education/Las TIC en el aprendizaje colaborativo en el aula de Primaria y Secundaria," Comunicar, vol. 21, no. 42, p. 65, 2014.

[22] M. linuma, "Learning and Teaching with Technology in the Knowledge Society: New Literacy, Collaboration and Digital Content", Springer, 2015.

[23] C. H. Muntean and J. McManis, "End-user quality of experience Ooriented adaptive e-learning system", in Journal of Digital Information, Special Issue on Adaptive Hypermedia, Vol. 7, No. 1, 2006

[24] M. Hampson, A. Patton, and L. Shanks, "Ten ideas for $21^{\text {st }}$ century education." The Innovation Unit, UK Government., 2013. 